\title{
Sosialisasi Pencegahan Demam Berdarah Dengue (DBD) Melalui Pelatihan Pembuatan Ovitrap Pada Masa Pandemi di SMP Muhammadiyah 1 Malang
}

\author{
${ }^{1}$ Ali Roziqin, ${ }^{2}$ Moh. Mirza Nuryady, ${ }^{2}$ Ahmad Fauzi, ${ }^{3}$ Yanur Setyaningrum \\ ${ }^{1}$ Prodi Ilmu Pemerintahan, FISIP, Universitas Muhammadiyah Malang, Indonesia \\ ${ }^{2}$ Prodi Pendidikan Biologi, FKIP, Universitas Muhammadiyah Malang, Indonesia \\ ${ }^{3}$ SMP Muhammadiyah 1 Malang, Indonesia
}

\section{Email Korespondensi: mirzanuryady@umm.ac.id}

\begin{tabular}{|c|c|}
\hline Article Info & Abstract \\
\hline $\begin{array}{l}\text { Article History } \\
\text { Received: } 2020-10-12 \\
\text { Revised: } 2020-10-19 \\
\text { Published: } 2020-10-30\end{array}$ & \multirow{2}{*}{$\begin{array}{l}\text { Malang City is one of the endemic areas which has a high incidence of dengue } \\
\text { fever (DHF). In addition, the effect of the Covid-19 pandemic, which requires } \\
\text { people to do more activities at home, allows the number of dengue infections to } \\
\text { increase so that prevention efforts are needed. The role of the community in } \\
\text { reducing the incidence of DHF is very vital, because the most effective } \\
\text { eradication of DHF is by vector control. One way to break the life cycle of a } \\
\text { mosquito is to make a mosquito egg trap (Ovitrap). However, the pandemic } \\
\text { limits the direct and massive outreach, in this case teacher has a key role in } \\
\text { disseminating information to students to remind students about clean living } \\
\text { habits (PHBS) in eradicating DHF. The method used to overcome this problem } \\
\text { is through the socialization of DHF prevention and workshop making ovitrap. } \\
\text { Located in the hall of SMP Muhammadiyah } 1 \text { Malang, there was counseling } \\
\text { about dengue disease, workshop on making ovitrap and also distributing } \\
\text { ovitrap to all participants. This program was attended by } 20 \text { participants. This } \\
\text { socialization aims to increase teachers' understanding of dengue fever, how to } \\
\text { handle it, how to make ovitrap, and increase teacher awareness to participate } \\
\text { in reminding students to always keep doing PHBS such as in eradicating } \\
\text { mosquito nests using the } 3 M \text { Plus method. The positive response, the } \\
\text { enthusiasm of the teacher towards the implementation of the socialization and } \\
\text { the post-test results which showed that the average teacher knowledge about } \\
\text { DHF was good, which could reflect the success of the program. }\end{array}$} \\
\hline $\begin{array}{l}\text { Keywords } \\
\text { Dengue Hemorrha } \\
\text { Fever } \\
\text { Ovitrap } \\
\text { Pandemic }\end{array}$ & \\
\hline Informasi Artikel & Abstrak \\
\hline $\begin{array}{l}\text { Sejarah Artikel } \\
\text { Diterima: } 12-10-2020 \\
\text { Direvisi: } 19-10-2020 \\
\text { Dipublikasi: } 30-10-2020\end{array}$ & \multirow{2}{*}{$\begin{array}{l}\text { Kota Malang menjadi salah satu daerah endemis yang memiliki insiden DBD } \\
\text { yang cukup tinggi. Disisi lain, efek pandemic covid-19 yang mengharuskan } \\
\text { masyarakat lebih banyak melakukan aktivitas di rumah, memungkinkan jumlah } \\
\text { infeksi DBD akan meningkat sehingga perlu upaya penanggulangan. Peran } \\
\text { masyarakat dalam penurunan angka kejadian DBD sangat vital, karena } \\
\text { pemberantasan DBD yang paling efektif yaitu dengan memutus siklus hidup } \\
\text { nyamuk. Salah satu cara untuk memutus siklus hidup nyamuk adalah dengan } \\
\text { membuat perangkap telur nyamuk (Ovitrap). Pada era pandemik aktivitas } \\
\text { sosialisasi tidak dapat dilakukan secara massive, dalam hal ini guru memiliki } \\
\text { peran kunci untuk menyebar luaskan informasi kepada siswa tentang prilaku } \\
\text { hidup bersih (PHBS) guna menanggulangi DBD. Sosialisasi ini bertujuan untuk } \\
\text { meningkatkan pemahaman guru tentang penyakit DBD, cara penanggulangan, } \\
\text { cara pembuatan ovitrap, dan nantinya guru dapat menyebar luaskan informasi } \\
\text { ini kepada siswa dan masyarakat luas. Metode yang dilakukan untuk mengatasi } \\
\text { masalah tersebut adalah melalui kegiatan sosialisasi pencegahan DBD dan } \\
\text { pembuatan ovitrap. Bertempat di aula SMP Muhammadiyah } 1 \text { Malang } \\
\text { dilaksanakan penyuluhan tentang penyakit DBD. Respon positif dan }\end{array}$} \\
\hline $\begin{array}{l}\text { Kata kunci } \\
\text { Demam Berdarah Dangue } \\
\text { Ovitrap } \\
\text { Pandemi }\end{array}$ & \\
\hline
\end{tabular}


antusiasme guru terhadap pelaksanaan sosialisasi ditunjukkan dari rata-rata pengetahuan guru tentang DBD yang baik.

Sitasi: Roziqin A., Nuryady M.M., Fauzi A., \& Setyaningrum Y. (2020) Sosialisasi Pencegahan Demam Berdarah Dengue (DBD) Melalui Pelatihan Pembuatan Ovitrap Pada Masa Pandemi di SMP Muhammadiyah 1 Malang. Sasambo: Jurnal Abdimas (Journal of Community Service). 2(3), 209-216 DOI : 10.36312/sasambo.v2i3.312

\section{PENDAHULUAN}

Penyakit Demam Berdarah Dengue (DBD) yang biasa disebut Dengue Haemorrahagic Fever (DHF) merupakan satu dari beberapa penyakit menular yang menjadi masalah kesehatan di dunia terutama negara berkembang. Infeksi penyakit DBD berimplikasi luas terhadap kerugian material dan moral berupa biaya rumah sakit dan pengobatan pasien, kehilangan produktivitas kerja bagi penderita, kehilangan wisatawan akibat pemberitaan buruk terhadap daerah kejadian dan yang paling fatal adalah kehilangan nyawa (Lloyd, 2003). Penyakit itu disebabkan oleh virus dari famili Flaviridae yang ditularkan oleh serangga (arthropod borne virus = arbovirus) (Supartha, 2008). Tingginya angka kejadian penyakit DBD dapat menjadi indikator tingginya populasi nyamuk Ae. aegypti di wilayah tersebut. Penularan penyakit DBD akan terus meningkat apabila kurang efektifnya upaya pemberantasan serta akibat tingginya kontak dengan nyamuk vektor DBD (Roche et al., 2015). Selain itu kasus DBD terkait erat dengan buruknya sanitasi lingkungan di daerah kejadian. Untuk mengantisipasi masalah tersebut diperlukan taktik dan strategi yang komprehensif melalui penelusuran informasi tentang bioekologi Ae. aegypti yang menyangkut karakter morfologi, biologi, dan kemampuan adaptasinya terhadap lingkungan. Berdasarkan informasi tersebut, dirumuskan suatu model pengendalian terpadu yang diharapkan mampu mencegah penularan dan bahaya penyakit tersebut. Jirakanjanakit et al., (2014) melaporkan beberapa cara pencegahan terpadu vektor tersebut sebagai bagian dari kerangka konsepnya dalam program pengendalian terpadu penyakit DBD di Amerika. Beberapa kajian dan kegiatan yang menyangkut program tersebut adalah kajian epidemiologi penyakit dan kajian entomologis vektor, pengelolaan lingkungan, advokasi dan program aksi kesehatan lintas instansi, partisipasi aktif masyarakat, pendidikan dan pelatihan petugas berkaitan dengan ilmu kesehatan dan ilmu sosial.

Saat ini pemerintah melalui Dinas Kesehatan selalu mengupayakan penekanan angka penderita DBD dengan 3 progran unggulan, yaitu: 1) peningkatan kegiatan surveillans penyakit dan vektor, 2) Diagnosis dini dan pengobatan dini, 3) Peningkatan upaya pemberantasan vektor penularan penyakit DBD (Kementerian Kesehatan Republik Indonesia, 2010). Upaya pemberantasan DBD dititik beratkan pada penggerakan potensi masyarakat untuk berperan serta dalam Pemberantasan Sarang Nyamuk (PSN) melalui 3M plus (menguras, menutup dan mengubur) plus menabur larvasida, penyebaran ikan pada tempat penampungan air, juru pemantau jentik (jumantik) untuk memantau angka bebas jentik (ABJ), penyebaran ovitrap, serta pengenalan gejala DBD dan penanganannya di rumah tangga. Angka bebas jentik (ABJ) digunakan sebagai tolok ukur upaya pemberantasan vektor DBD (I Wayan Supartha, 2008).

Kota Malang adalah salah satu kota besar di Jawa Timur. Jumlah penduduk Kota Malang Tahun 2018 berdasarkan angka proyeksi adalah 866.118 jiwa dengan tingkat kepadatan penduduk 7.869,51 jiwa/ Km2 (Dinkes, 2019). Tingginya tingkat kepadatan penduduk di Kota Malang juga berdampak dengan timbulnya penyakit di masyarakat, salah satu contoh penyakit yang sering ditemukan di daerah padat peduduk adalah penyakit berbasis vektor seperti Demam Berdarah Dengue (DBD). Kota Malang menjadi salah satu daerah endemis yang memiliki insiden DBD yang cukup tinggi dengan angka kematian 
mencapai 0,80\% pada tahun 1998 (Soegijanto, 2006). Menurut Dinas Kesehatan Kota Malang (2008), pada tahun 2007 tercatat 642 penderita dengan 10 orang meninggal dunia. Pada tahun 2018 jumlah penderita DBD di kota malang terbilang menurun di bandingkan dengan 5 tahun terakhir yaitu sebesar 73 kasus dengan 1 orang meninggal dunia (Dinkes, 2019).

Pandemi yang terjadi selama tahun 2020 mewajibkan hampir seluruh kegiatan dilakukan dari dalam rumah (Work From Home). Hal ini tentu akan berdampak terhadap kejadian indfeksi DBD mengingat preferensi menggigit nyamuk Aedes aegypti adalah orang yang berada di dalam rumah. Seluruh pihak harus turut berpartisipasi untuk mencegah kejadian DBD pada masa pandemik. Bidang pendidikan dalam hal ini adalah guru memiliki peran besar dalam mengedukasi siswa sebagai vektor DBD. Siswa diwajibkan untuk tetap memperhatikan sanitasi lingkungan dan berprilaku hidup bersih dan sehat (PHBS) guna mencegah penularan DBD. Guru juga berperan sangat vital untuk mengedukasi masyarakat dalam penurunan angka kejadian DBD. Pencegahan DBD yang paling efektif yaitu dengan memutus siklus hidup nyamuk (vektor kontrol) (Santiago, 2008). Pemutusan siklus hidup nyamuk salah satunya dapat dilakukan dengan cara menyebar perangkap telur nyamuk (Ovitrap). SMP Muhammadiyah 1 Malang terletak di tengah kota Malang, dengan siswa yang berasal dari beberapa kecamatan di kota Malang. Pemahaman tentang cara penanggulangan DBD haruslah dimiliki oleh masyarakat umum, khususnya para guru dan siswa di SMP Muhammadiyah 1 Malang. Oleh karena itu tujuan sosialisasi bertujuan agar meningkatkan pemahaman guru tentang cara penanggulangan DBD, cara pembuatan ovitrap, serta nantinya guru dapat menyebar luaskan informasi ini kepada siswa dan masyarakat luas.

\section{METODE}

Berdasarkan analisis situasi diperlukan upaya untuk meningkatkan pemahaman dan kesadaran masyarakat khususnya guru di SMP Muhammadiyah 1 Malang sebagai pemegang kunci penyebar informasi pada masa pandemi seperti saat ini, dalam upaya menanggulangi penyakit DBD. Metode yang dilakukan untuk mengatasi masalah tersebut adalah sebagai berikut:

1. Analisis Masalah Mitra

Analisis masalah mitra dilaksanakan dengan melakukan wawancara dan diskusi secara langsung dengan stake holder terkait seperti SMP Muhammadiyah 1Malang, Puskesmas Bareng, Rumah Sakit Pendidikan UMM.

2. Sosialisasi pencegahan DBD

Sosialisasi dilakukan kepada seluruh peserta yaitu tenaga pendidik di lingkungan SMP Muhammadiyah 1 Malang. Sebelumnya tim pengabdian melakukan mini research untuk menentukan lokasi mana yang paling tepat untuk dilakukan tempat pengabdia. Setelah melihat data timeseries angka kejadian DBD di Kota Malang, Kecamatan Klojen memiliki rata-rata yang cukup tinggi. Tim juga mempersiapkan media untuk sosialisasi dan melalukan pre-test untuk mengetahui pengetauan awal dari para guru tentang materi yang akan disampaikan. Materi sosialisasi dipresentasikan langsung oleh praktisi dari Rumah Sakit Universitas Muhammadiyah Malang.

3. Pelatihan pembuatan ovitrap

Tim pengabdian sebelumnya telah membuat ovitrap dengan alat dan bahan seperti botol air minum bekas berukuran $1500 \mathrm{ml}$, gunting, kawat. Pembuatan ovitrap dilakukan dengan menggunting botol menjadi dua bagian, bagian botol dengan leher di telungkupkan kebagian lainnya, disatukan dengan kawat, diisi air dan diletakkan di bagian pojok rumah. Ovitrap digunakan sebagai media perangkap terhadap nyamuk untuk bersarang dan bertelur (Santiago, 2008). Selanjutnya tim memaparkan secara langsung proses pembuatannya kepada seluruh peserta pelatihan. Tim juga membagikan sebanyak 100 ovitrap gratis kepada pihak mitra untuk dibagikan ke seluruh guru dan staf di SMP 
Muhammadiyah 1 Malang. Secara keseluruhan kegiatan ini juga didokumentasikan dengan video yang kemudian disebarluaskan melalui kanal youtube, termasuk tutorial pembuatan ovitrap. Tahapan selanjutnya adalah survei pengetahuan guru tentang pencegahan dan penanganan dini DBD, dan pelaporan hasil.

\section{HASIL DAN PEMBAHASAN}

Berdasarkan hasil kegiatan sosialisasi dapat terlihat bahwa para peserta yang terdiri atas sivitas akademik dan para guru di SMP Muhammadiyah 1 Malang sangat antusias dalam mengikuti kegiatan tersebut. Terdapat 3 Acara inti yang dilakukan dalam rangkaian acara pengabdian masyarakat ini:

\section{Diskusi dan Wawancara}

Kegiatan pertama yaitu melakukan wawancara dan diskusi dengan beberapa pihak dan stakeholder terkait. Tim pengabdian melakukan wawancara dengan pimpinan Puskesmas Bareng Kota Malang beserta tim juru pemantau jentik. Hasil wawancara yaitu, selain penerapan Perilaku Hidup Bersih yang teratur (3M Plus), menjaga sanitasi lingkungan yang baik pihak puskesmas menyarankan untuk memutus siklus hidup nyamuk dengan cara memantau jentik disetiap bak penampungan air dan membuat jebakan telur nyamuk. Pembuatan jebakan telur nyamuk (ovitrap) akan sangat ampuh untuk memutus siklus hidup nyamuk, hal ini disebabkan karena penggunaan ovitrap lebih aman dan ramah lingkungan dibandingkan dengan penggunaan insektisida (Hairani et al., 2020). Pada umumnya masyarakat belum mengetahui cara pembuatan ovitrap, yang sesungguhnya cara pembuatannya cukup simple dan murah. Sehingga penting untuk para guru memahami cara pembuatan ovitrap agar guru dapat menyebar luaskan informasi tersebut pada siswanya yang sedang belajar dari rumah.

Pentingnya upaya pencegahan dan tindakan preventif ini bertujuan untuk menyadarkan masyarakat akan pentingnya kegiatan penanggulangan terhadap penularan penyakit DBD, terutama yang disebabkan oleh kurangnya kesadaran diri akan pentingnya menjaga dan memelihara lingkungan (Rau, Soraya and Pitriani, 2019). Oleh karena itu, adanya pemberdayaan masyarakat dalam kegiatan pemberantasan sarang nyamuk (PSN) dengan 3M Plus merupakan salah satu cara ampuh yang dapat dilakukan sebagai upaya untuk menanggulangi peningkatan terhadap tingginya kasus DBD (Pratamawati, 2012), karena adanya keikutsertaan masyarakat secara aktif dalam pemantauan vektor nyamuk secara berkala diyakini dapat mempercepat pemberantasan terhadap tempat perkembang biakan vektor (Sumarni, Rosidin and Witdiawati, 2019).

Selain itu, adanya tindakan preventif terhadap pengendalian vektor ini juga merupakan salah satu metode utama yang dapat digunakan dalam pencegahan DBD, karena mengingat vaksin dan antivirus yang efektif untuk penderita DBD belum tersedia (Dhurhania and Novianto, 2018). Maka, beberapa bentuk inovasi dan peningkatan peran terhadap edukasi masyarakat mengenai jumantik dan jebakan telur nyamuk tentunya akan memberikan pengaruh positif dan perubahan signifikan terhadap pola dan prilaku masyarakat (Susianti, 2019). Sehingga upaya perlindungan diri terhadap penyakit demam berdarah dangue ini bukan hanya menjadi tugas dan tanggung jawab dari pemerintah saja, melainkan dari seluruh elemen masyarakat, karena tanpa adanya kerjasama yang baik antara pemerintah dan masyarakat, maka tidak akan ada hasil yang maksimal dari suatu program.

\section{Sosialisasi dan Pelatihan}

Kegiatan sosialisasi dilaksanakan di aula SMP Muhammadiyah 1 Malang yang dihadiri oleh staf dan para guru berjumlah 17 orang dengan menerapkan protokol kesehatan yang ketat. Guru berperan sangat penting untuk menyebar luaskan informasi ini, agar ketika siswa yang sedang belajar dirumah bisa diingatkan untuk melakukan PHBS untuk mencegah DBD dan juga dapat menularkan ilmu pembuatan ovitrap kepada seluruh siswanya. Pada kegiatan sosialisasi para guru sangat antusias untuk mendengarkan pemaparan dari salah satu 
dokter dari Rumah Sakit Universitas Muhammadiyah Malang. Pada akhir sesi dilakukan survey pengetahuan guru tentang hal-hal yang berkaitan dengan Demam Berdarah Dengue.

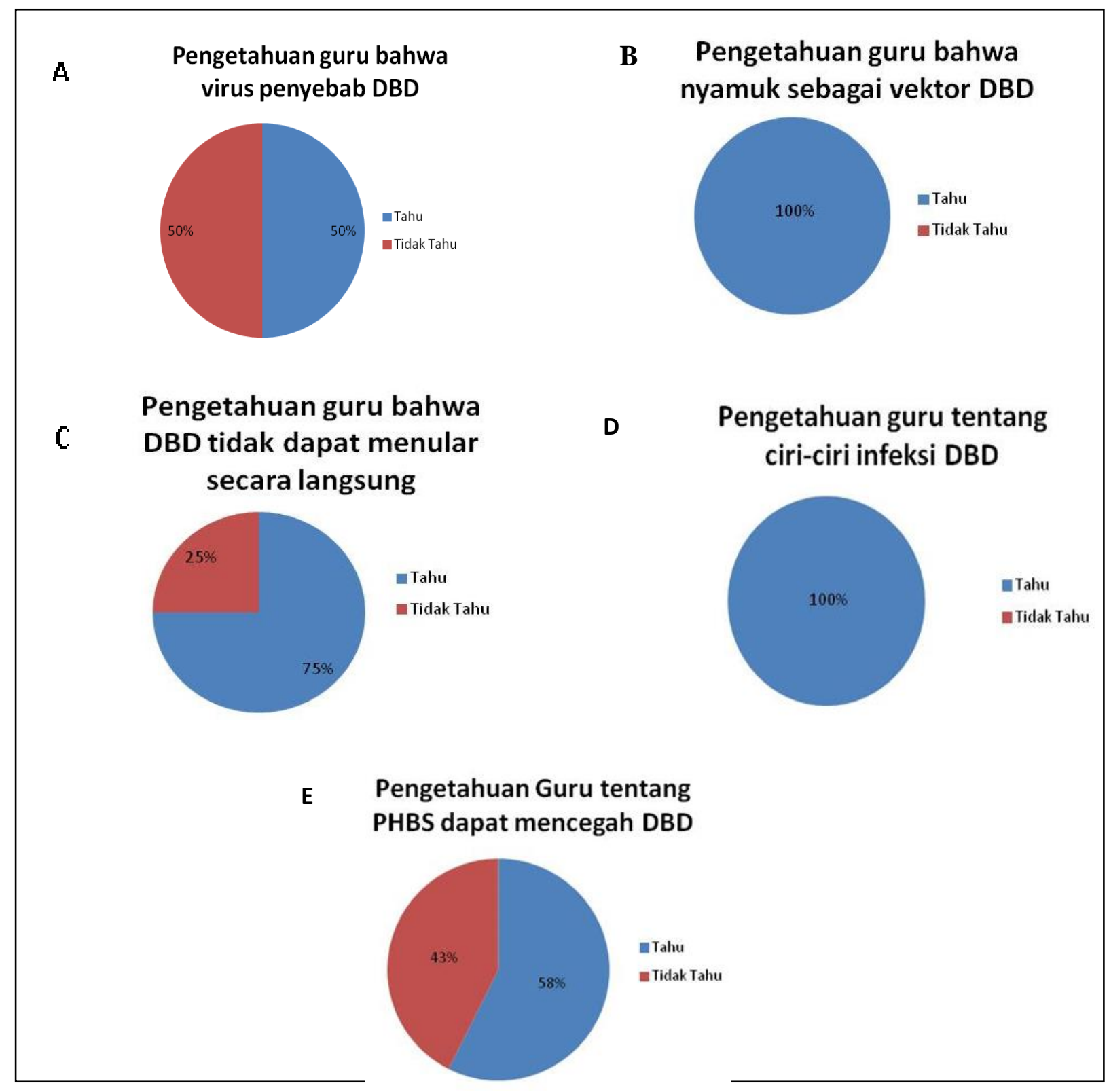

Gambar 1. Hasil survey pengetahuan guru tentang beberapa pengetahuan terkait DBD

Hasil survei setelah sosialisasi menunjukkan rata-rata guru telah memahami tentang DBD disebabkan oleh vektor yaitu nyamuk Aedes sp., dan ciri-ciri apabila orang terinfeksi virus dengue, sedangkan diatas guru yang mengetahui penyebab penyakit DBD adalah virus, cara penularan DBD, serta tentang cara pencegahan DBD dengan PHBS secara berurutan yaitu $50 \%, 75 \%, 58 \%$. Hasil ini sudah menunjukkan bahwa pemahaman guru tentang DBD sudah cukup baik meskipun masih dibutuhkan upaya sejenis untuk dapat lebih efektif meningkatkan pengetahuan guru tentang DBD. Semua materi disampaikan dengan baik dan dapat diterima dan dipahami oleh para peserta dengan baik. Hasil evaluasi secara lisan yang telah Tim Pengmas lakukan menggambarkan bahwa para peserta memahami materi yang telah disampaikan. Hal ini terlihat dari kemampuan mereka menjawab dengan baik dan benar sebagai evaluasi dalam keberhasilan peningkatan pengetahuan mengenai cara pencegahan dan pemberantasan penyakit DBD. Hal ini sesuai dengan pengabdian yang dilakukan oleh 
Rubandiyah and Nugroho (2018) yang menyatakan pengetahuan kader jumantik akan meningkat dengan program pelatihan dan sosialisais.

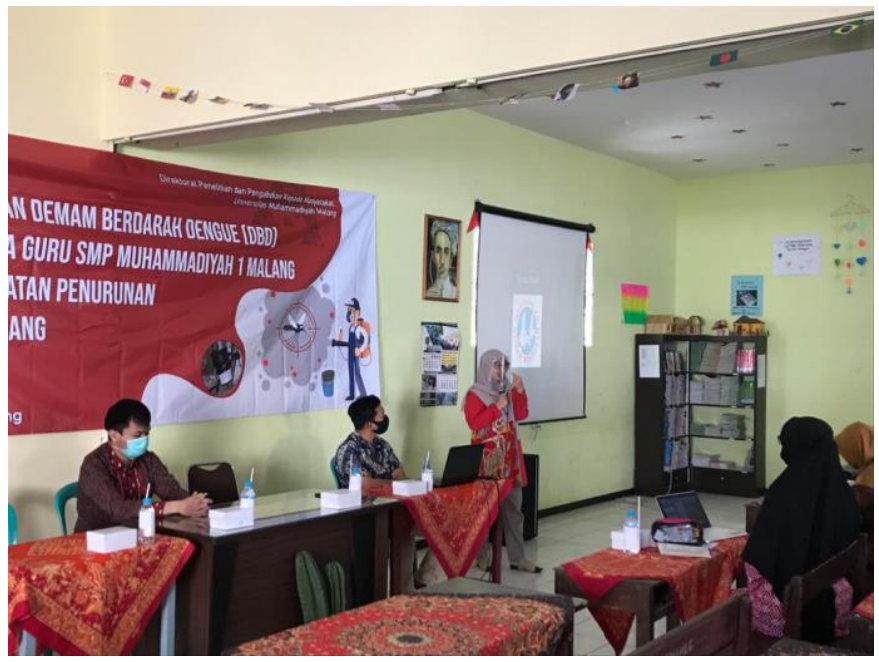

Gambar 2. Kegiatan sosialisasi tentang pengenalan, pencegahan DBD oleh dokter dari RS UMM

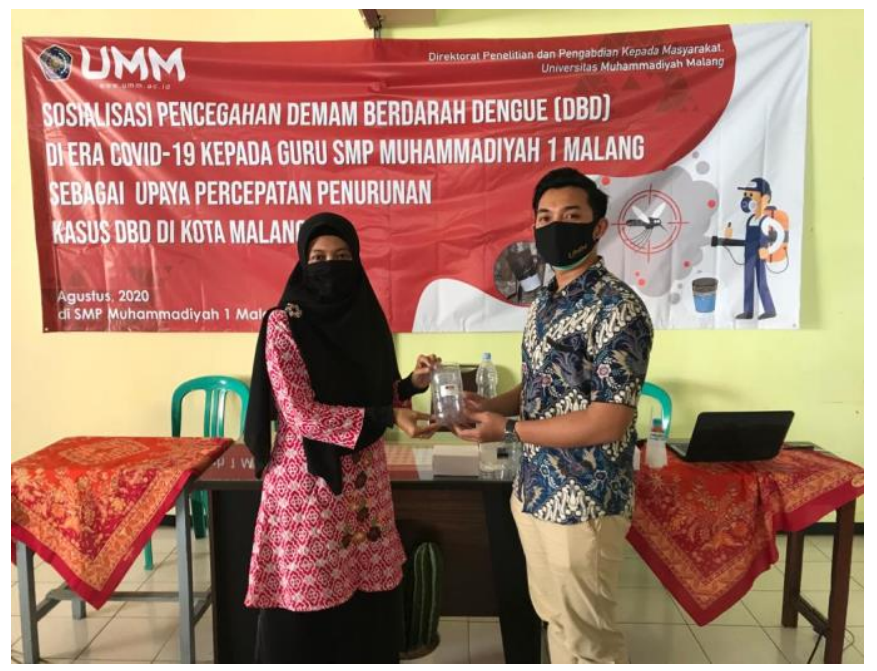

Gambar 3. Penyerahan ovitrap secara simbolik kepada kepala sekolah SMP Muhammadiyah 1 Malang setelah pelatihan pembuatan ovitrap selesai

Program pengabdian kepada masyarakat yang digagas ini tentu berdasarkan analisis kebutuhan dan kekhawatiran pihak mitra tentang isu infeksi demam berdarah dengue. Terlaksananya program didasarkan atas teori partisipasi masyarakat, yaitu suatu kegiatan tidak akan berhasil apabila tidak ada partisipasi dari masyarakat. Salam (2010) mengemukakan beberapa pola atau kondisi seseorang akan berpartisipasi, yaitu jika kegiatan tersebut dianggap penting bagi mereka, tindakan mereka akan membuat suatu perubahan, diakui dan dihargai adanya perbedaan-perbedaan partisipasi, serta kemungkinan mereka untuk berpartisipasi. Masyarakat yang dilibatkan secara optimal melalui musyawarah dan mufakat dalam kegiatan perencanaan dan pengembangan akan berdampak pada berjalannya program (Abikusno, 2005)

\section{KESIMPULAN}

Dari kegiatan sosialisasi tentang pencegahan DBD dan pelatihan pembuatan ovitrap yang dilakukan, dapat disimpulkan bahwa para peserta merasa lebih paham tentang cara penanggulangan dan dapat meneruskan informasi kepada siswa dan masyarakat luas. Hal ini 
dikarenakan para peserta mendapat pemahaman dan keterampilan baru dalam mencegah DBD. Selain itu, kegiatan penyampaian yang dilakukan dengan santai dan interaktif membuat para peserta dapat mengikuti kegiatan ini dengan sangat baik dari awal sampai akhir. Dari evaluasi yang dilakukan, para guru sudah cukup baik pemahamannya tentang DBD, namun saran yang diberikan adalah waktu pelatihan yang lebih lama dan berkesinambungan.

\section{SARAN}

Pengabdian selanjutnya yang bisa dilakukan oleh tim adalah meningkatkan jangkauan peserta yang lebih luas seperti misalnya ke sebagian peserta didik SMP atau SMA. Apalagi pada usia ini adalah peserta harus mengetahui dasar pengetahuan penting yang mempunyai dampak sosial kesehatan.

\section{UCAPAN TERIMA KASIH}

Terimakasih kami ucapkan kepada DPPM (Direktorat Penelitian dan Pengabdian Masyarakat) Universitas Muhammadiyah Malang dan SMP Muhammadiyah 1 Malang.

\section{DAFTAR PUSTAKA}

Abikusno, N. (2005) 'Model pendekatan bio-psiko-sosial pada masa pensiun', Universa Medicina, 24(2), pp. 103-110.

Dhurhania, C. E. and Novianto, A. (2018) 'Upaya Preventif Dan Kuratif Demam Berdarah Melalui Pemanfaatan Herbal Berkhasiat Di Desa Gadingan Kabupaten Sukoharjo Provinsi Jawa Tengah', Jurnal Pengabdian Kepada Masyarakat, 24(2), p. 629. doi: 10.24114/jpkm.v24i2.10116.

Dinkes, kota malang (2019) Profil kesehatan malang 2018. malang.

Hairani, B. et al. (2020) 'Efektivitas Air Rendaman Jerami Alang-Alang (Imperata cylindrica) sebagai Atraktan terhadap Jumlah Telur Aedes aegypti', Balaba: Jurnal Litbang Pengendalian Penyakit Bersumber Binatang Banjarnegara, pp. 39-46.

Jirakanjanakit, N. et al. (2014) 'Insecticide susceptible/resistance status in Aedes (Stegomyia) aegypti and Aedes (Stegomyia) albopictus (Diptera: Culicidae) in Thailand during 2003-2005', Journal of Economic Entomology. Entomological Society of America, 100(2), pp. 545-550.

Jusman Rau, M., Soraya, N. and Pitriani (2019) 'Faktor-Faktor Yang Berhubungan Dengan Upaya Pencegahan Demam Berdarah Dengue (DBD) di Kelurahan Birobuli Selatan', Jurnal Kesehatan Masyarakat, 10(2), pp. 73-82.

Kementerian Kesehatan Republik Indonesia (2010) 'Jendela Epidemiologi'. Jakarta

Lloyd, L. S. (2003) Strategic Report-EHP Enviromental Health Project, Best Practices for Dengue Prevention and Control in the Americas.

Pratamawati, D. A. (2012) 'Peran Juru Pantau Jentik dalam Sistem Kewaspadaan Dini Demam Berdarah Dengue di Indonesia', Kesmas: National Public Health Journal, 6(6), p. 243. doi: 10.21109/kesmas.v6i6.76.

Roche, B. et al. (2015) 'The spread of Aedes albopictus in metropolitan France: contribution of environmental drivers and human activities and predictions for a near future', PloS one. Public Library of Science, 10(5), p. e0125600.

Rubandiyah, H. I. and Nugroho, E. (2018) 'Pembentukan Kader Jumantik sebagai Upaya Peningkatan Pengetahuan Siswa di Sekolah Dasar', HIGEIA (Journal of Public Health Research and Development), 2(2), pp. 216-226.

Salam, M. R. (2010) 'Partisipasi Masyarakat dalam Peningkatan Kualitas Permukiman di Kawasan Kota Palu', Jurnal Ruang, 2(2), pp. 8-23.

Santiago, A. T. A. (2008) 'Aedes sp. Surveillance Using Ovitrap Technique in Barangay Sta. Cruz, Makati City, Philippines', Journal of Research in Science, Computing and Engineering, 4(1). doi: 10.3860/jrsce.v4i1.439. 
Soegijanto, S. (2006) Demam Berdarah Dengue Edisi 2, Airlangga University Press. Hal. surabay: Airlangga University Press.

Sumarni, N., Rosidin, U. and Witdiawati, W. (2019) 'Pengetahuan dan Sikap Masyarakat dalam Pencegahan dan Pemberantasan Jentik Nyamuk Demam Berdarah Dengue (DBD) Di Jayaraga Garut', ASPIRATOR - Journal of Vector-borne Disease Studies, 11(2), pp. 113-120. doi: 10.22435/asp.v11i2.1370.

Supartha, I Wayan (2008) Pengendalian terpadu vektor virus demam berdarah dengue , Aedes aegypti ( Linn .).

Supartha, I. W (2008) 'Pengendalian Terpadu Vektor Virus Demam Berdarah Dengue , Aedes aegypti ( Linn .) dan Aedes albopictus ( Skuse )( Diptera: Culicidae )', (September), pp. 3-6.

Susianti, N. (2019) 'Strategi Pemerintah Dalam Pemberantasan Demam Berdarah Dengue (Dbd) Di Kabupaten Merangin', Buletin Penelitian Sistem Kesehatan, 22(1), pp. 34-43. doi: 10.22435/hsr.v22i1.1799. 